\title{
From the ICELW 2011 Conference Chair
}

\author{
http://dx.doi.org/ijac.v4i3.1763
}

It has again been my pleasure to chair the fourth annual International Conference on E-Learning in the Workplace (ICELW) in 2011. We again had a large number of sessions that included demonstrations of elearning work, as well as excellent keynote speakers, Jay Cross and Jay Liebowitz, and a fascinating "allstar" panel discussion on the future of corporate learning and performance, led by Hal Christensen, featuring both Jay Cross and Jay Liebowitz along with Allison Rossett and Tony O’Driscoll.

One of the exciting developments at ICELW this year was an increased focus on just-in-time "performance support" along with training. In my own consulting work, I have often seen companies rely on training, whether classroom or online, when performance support methods (used by employees on-the-job, just when they need them) could be more effective. With the increased popularity of social media and a greater corporate emphasis on the value of informal learning, we are seeing, in many cases, a reduction in training and more performance support.

Once again this year, we remain at a time of great potential in workplace e-learning. Technology has people excited about the possibilities; the true progress in my mind, however, will be in the ways that we can design pedagogically-sound e-learning and usable, effective performance support products and methods. We want to provide an engaging, effective experience for the learner - one that has an impact on job performance.

Both ICELW and iJAC are avenues through which we can integrate research and practice in order to improve job performance. Our mix of researchers and practitioners at ICELW and in iJAC is, in my view, one of the strengths of both the conference and the journal, as we look to advance the field in ways that are practical yet based on research and theory.

Traditionally, we have dedicated an annual issue of iJAC to the top papers from that year's ICELW conference. This year, we have so many high-quality contributions from ICELW that they will be included in two iJAC issues, both this one and the following issue. The papers in this issue address a wide range of topics that demonstrate advancements in online learning. They cover topics such as pedagogical models and e-learning techniques [1], [4], [6], online mentoring and communication systems [3], [5] and a case study centered around training hotel employees [2]. I was pleased to see such an exceptional group of papers and presentations at ICELW 2011.

I would like to thank all of our presenters and participants, as well as our Executive Committee, International Program Committee, keynote speakers, and our wonderful staff, for a great ICELW 2011, as we already look toward ICELW 2012, to be held from June 13-15, 2012, again at Columbia University in New York. As always, I look forward to seeing continued work from iJAC and ICELW play a major role in influencing and improving the field of e-learning in the workplace.

\section{David Guralnick}

Chair, International Conference on E-Learning in the Workplace

Senior Editor, iJAC

President, International E-Learning Association

President, Kaleidoscope Learning

Adjunct Professor, Columbia University

[1] Patricia Alejandra Behar, "Constructing Pedagogical Models For E-learning”, Int. Journal of Advanced Corporate Learning, 4, 3, pp. 16-22, http://dx.doi.org/ijac.v4i3.1713

[2] S. A. Assis, H. Abdalla and G. H. Pftischer, "World Cup 2014 - Professional Training Program for Brazilian Hotels", Int. Journal of Advanced Corporate Learning, 4, 3, pp. 10-15, http://dx.doi.org/ijac.v4i3.1714

[3] Barbara Schwartz-Bechet, "Professional Partnerships: Supporting the Preparation of Pre-Service Teachers Through a Tiered Online Mentoring System”, Int. Journal of Advanced Corporate Learning, 4, 3, pp. 35-38, http://dx.doi.org/ijac.v4i3.1718

[4] Kai Erenli and Gerhard Ortner, "Collaborative and Social Learning using Virtual Worlds: Preparing Students for Virtually Anything", Int. Journal of Advanced Corporate Learning, 4, 3, pp. 23-29, http://dx.doi.org/ijac.v4i3.1734

[5] Line Skov Hansen, Anne-Karin Sunnevåg and Anne Kostøl, "E-Learning and School Development - Strengths and Challenges of Capacity Building in School Development Projects", Int. Journal of Advanced Corporate Learning, 4, 3, pp. 30-34, http://dx.doi.org/ijac.v4i3.1737

[6] Nikolaos Antoniadis and Dimitrios Konetas, "Correlation between Awareness of Blended Learning Techniques and Participation Rate in Elearning: a Case Study", http://dx.doi.org/ijac.v4i3.1738 